\title{
HEADING TOWARDS COLLAPSE? ASSESSMENT OF THE SLOVAK PARTY SYSTEM AFTER THE 2020 GENERAL ELECTIONS ${ }^{1}$
}

\author{
Alexandra Smolecová2, Daniel Šárovec ${ }^{3}$
}

\begin{abstract}
This article aims to analyse changes of the Slovak party system from 1992 to the last parliamentary elections of 2020. These elections were the eighth elections in the history of independent Slovakia. There are discussions about stability or instability of individual development stages of the party system. In the article, Attention is paid to changes in the distribution of forces within the development of the party system. In political science, various methods are used to measure the party system's dynamics to determine the intensity of changes and the trends arising from them. This analysis is based on election results in each electoral cycle (period), which are being compared. Next part of the analysis is focused on the selected comparative indicators: Index of the Effective Number of Parties and Aggregation Index. These indices are chosen based on the criteria of classification of party systems. The results presented in the final part of the paper prove that several significant milestones in development of party system could be identified, as confirmed by the 2020 general elections - a major breakthrough in development trends.
\end{abstract}

KEY WORDS: Slovakia, Party system, Slovak party system, Political party, Party system change, Elections, Slovak parliamentary election.

\section{INTRODUCTION}

The 2020 parliamentary elections to the National Council of the Slovak Republic (hereinafter referred to as "parliamentary elections") were highly awaited by whole country. They completed the another stage of the modern development of Slovakia, and at the same time, they were held in atmosphere of protests against the social and political events (for example, the murder of a journalist and his fiancée, as well as the rise of the far right

\footnotetext{
${ }^{1}$ This study was supported by the Charles University Research Programme "Progres" Q18 Social Sciences: From Multidisciplinarity to Interdisciplinarity.

${ }^{2}$ Faculty of Social Sciences, Charles University, Pekařská 16, 15800 Prague, Czech Republic. E-mail: alex.smolec@gmail.com.

${ }^{3}$ Faculty of Social Sciences, Charles University, Pekařská 16, 15800 Prague, Czech Republic. E-mail: daniel.sarovec@fsv.cuni.cz. ORCID 0000-0003-2491-538X.
} 
and the subsequent division of society, and demonstrations against some corruption cases). To some extent, these elections could be perceived as extremely important opportunity for the Slovak society, which voiced its opinion on the direction desired after the above turbulent social events.

The aim of this study is to focus on the trends of the dynamics of the Slovak party system from 1992 to 2020. From a historical point of view, the 1990 Slovak parliamentary election are perceived as the first free elections, referred to as the founding elections, or an "informal referendum" on the direction of the transition process. Probably the biggest ideological dispute took place here between Public Against Violence (Verejnost' proti násiliu) and Communist Party of Czechoslovakia/Slovakia (Komunistická strana Československa/Slovenska). These elections introduced a 3 per cent threshold, and the subsequent elections in 1992 had risen this threshold to $5 \%$ altogether with a change in formula of seats allocation (from Hare to Hagenbach-Bischoff quota, see Šedo, 2008: 36).

After the split of the federation in 1993, the Slovak National Council transformed into the National Council of the Slovak Republic. Therefore, the analysis identified parliamentary election held in 1992 as the first elections. The year 2020 then finalises the research period, as in 2020 last parliamentary elections were held (comp. with Linek, Gyárfášová, 2020).

The main dimension under review is comprised by parliamentary elections, being the first-order elections (FOE), with an emphasis on the 2020 elections. The analysis draws on a systematic overview covering the current state of knowledge. The 2020 elections are considered rather attractive research topic in this regard. They could confirm the continuity of the party system development the current "party hegemon" - SMER-SD party, or reverse the development in a completely different direction. "The results showed that the leading force on the political scene will be another party - OLANO."

However, some authors defined the 2016 elections as those fundamental and ground-breaking (Charvát, Just, 2018), a certain breakthrough and a change were also expected from the 2020 elections. In the context of the 2020 elections, the term crucial elections (Gyárfášová, 2020) even appeared. The article, therefore, aims to answer the following research questions: "What are the development trends of the Slovak party system based on selected comparative indicators in 1992-2020?" and "What factors caused the 2020 parliamentary elections were distinctive "

Therefore, the first part provides a basic overview of the main characteristics of the Slovak party system from the independent beginnings to the present. 
The methodological chapter aims to define the analytical framework, which derives from the use of selected comparative indicators for research into the development of party systems.

The analytical part focuses on defining the main development trends of the party system from 1992 to 2020 . The concluding part then deals in more detail with the most current phenomenon of 2020 parliamentary elections.

\section{KEY CHARACTERISTICS OF THE SLOVAK PARTY SYSTEM}

Research devoted to political parties and partisanship in Central Europe lies in the focus of many authors (e.g. Szczerbiak, Hanley, 2006; Bakke, Sitter, 2015; Deegan-Krause, Haughton, 2015 or Engler 2020) ${ }^{4}$. This is significant topic can be explored from many aspects and development tendencies of the Slovak party system and Slovak politics are more generally analysed by many authors (e.g. Gyárfášová, Mesežnikov, 2004; Kopeček, 2006; Mesežnikov, 2013; Stískala, 2014; Štefančík, Nemcová, 2015 or Naxera, Krčál 2017). A comparison of Slovakia and the Czech Republic are also not uncommon (e.g. Deegan-Krause, 2006; Voda, Pink, 2015; Žúborová, 2015 or Frič, Gyárfášová, 2019). It turns out that Slovak politics is a constant subject of research by many authors not only from Central Europe.

After 1989, there was a gradual renewal of the pluralist party system in Slovakia. ${ }^{5}$ After 1992, the conflict line between Vladimír Mečiar's politics with autocratic characteristics and an anti-coalition formed against him was sharping. Therefore, experts could observe a higher degree of polarization in society and politics, which culminated in 1994. A new term of "Mečiarism" was coined to characterise the Mečiar's politics and was introduced also to expert works with a counter-position called "anti-Mečiarism" (see Fish, 1999; Baer, 2001 and Kopeček, 2006, p. 462-468).

However, there are also opinions that the suffix "-ism" should not be used in this way. Stanislav Kirschbaum (2002, p. 138) disputes about this in his response to Kieran Williams' approach (2000): "It is not clear why the evidence of such policies make up an "ism", especially as there is neither a fundamental text nor a series of speeches by Vladimír Mečiar, the longest

\footnotetext{
${ }^{4}$ For a more detailed analysis of the development of party systems in Central Europe, see, e.g., the case of the Czech Republic (Šárovec, 2019) or Poland (Kosowska-Gąstoł, SobolewskaMyślik, 2019). For a theoretical insight see, e.g., Šárovec (2020).

${ }^{5}$ Cleavages within the Slovak party system see in Leška (2013), Bardovič (2016, pp. 104-108) or Just (2019, pp. 78-79). Aspects of government formation see in Just (2018; 2019).
} 
serving prime minister of post-communist Slovakia, that would allow to speak of an ideology linked to him. "

The 1998 elections with Mečiar defeated had caused an erosion of this conflict line, leading to the transition to moderate pluralism. It is comparable with hypothesized relationships among issue divides in sixteen postcommunist countries during the 1990s. Slovakia is marked as pro-NATION vs. anti-NATION \& anti-ACCOUNTABILITY vs. pro-ACCOUNTABILITY within issue divides, as defined by Deegan-Krause. Crosscutting issue divides were pro-church/pro-market vs. anti-church/anti-market (Deegan-Krause, 2006, p. 234).

This path was evident even after the 2002 elections, followed by a complete alternation of the governing coalition after the 2006 elections. After 2010, the ruling coalition completely changed again, the SMER-SD government was replaced by a coalition of centre-right parties with the then Prime Minister Iveta Radičová, a leader of SDKÚ-DS. ${ }^{6}$ The early elections held in 2012 were won by SMER-SD due to $44.4 \%$ of the votes cast. The party then formed a "one-colour" government. It is, therefore, possible to speak of an era of multipartism with a dominant party (see Kopeček, 2006 and Leška, 2013). The 2016 elections were then identified by many authors as a "political or party earthquake" (Charvát, Just, 2018 or Kerekeš, Pink, Šedo, 2019), because a number of new changes occured in the party competition. So far, the most recent 2020 elections can be characterized as another important milestone. Victory of OLaNO party has once again redrawn the political map of Slovakia.

In essence, since the split of the federation in 1993, the Slovak party system has permanently been oscillating on the border between limited and extreme pluralism (Cabada, Hloušek, Jurek, 2013, p. 88). The Slovak party system is considered unstable and fragmented, due to such phenomena as a weak institutionalization of some stakeholders, their frequent party fluctuation and high level of personification of politics (Hynčica, Šárovec, 2018, p. 11).

However, this development needs to be related to the relatively inconsistent terms, which characterize the Slovak party system as "more or less stable", "relatively unstable" or "relatively significantly stable" (see Charvát, Just, 2018, p. 38-39 and Filipec, 2019, p. 9). This discussion reveals difficulty of defining a clear notion. However, undoubtedly it is most likely not possible to speak of clear lasting stability from a complex point of view.

${ }^{6}$ Coalition of the following parties - SDKÚ-DS, SaS, Most-HÍD and KDH. 


\section{DATA AND METHODS 7}

This study focused on the development dynamics of the Slovak party system, and compares in more detail the individual elections to the National Council of the Slovak Republic from $1992^{8}$ to 2020 . A comparative analysis is based on a comparison of election results and seats distribution of individual political parties in the Parliament.

Data for the comparison are from the electronic archive of the Statistical Office of the Slovak Republic (see Volby.statistics.sk, 2020), available for each elections. The analysis works with the dimension of comparison of individual parliamentary entities, whose election results are compared in the research period. On this basis, the authors consequently compare the number of entities successfully competing in the parliamentary elections during 1992-2020.

Original calculations of comparative indicators are used for the analysis of the dynamics of the party system development. The Index of the Effective Number of Parties and the Aggregation Index were chosen as indexes representing the study of the party system fragmentation (Lebeda, 2019, p. 576).

Such oriented research outputs already exist within the existing state of knowledge (see Brunclík, 2014 or Novotný, Šárovec, 2018). The text intentionally omits, for example, the Pedersen Volatility Index, which in the context of the topic studied here can be considered so complex and broad that it can be devoted to a separate piece of study. (see Gyárfášová, Bahna, Slosiarik, 2017; Charvát, Just, 2018 or Linek, Gyárfášová, 2020).

The Index of the Effective Number of Parties was designed by Markku Laakso and Rein Taagepera (1979). The index measures the size of the party system according to how many political parties fit into it, judged on the basis of their size, which reflects their electoral strength within the party system. The index can be calculated in two ways: at the electoral and parliamentary level.

$$
N=1 / \sum_{i=1}^{n} p_{i}^{2}
$$

${ }^{7}$ Chapters 2 and 3 partly reflect basic findings by Smolecová (2019).

${ }^{8}$ In 1992 the general elections were held as election to the Slovak National Council, after 1993 this body was transformed to the National Council, and therefore these general elections are called elections to the National Council. 
In the formula for calculating, $N$ represents the effective number of parties, $n$ represents the total number of parties, $p_{i}$ is the percentage of seats (parliamentary level) or the percentage of votes obtained (electoral level) for a given party $i$.

The index is equal to 1 if there is only one party in the party system. The value of the index increases with the increasing number of parties. If there is any number of parties of the same size, and their voting power is the same, then the effective number of these parties corresponds to the actual situation. If two parties have $50 \%$ of the seats in parliament (they both won $50 \%$ of the votes in the elections), then the value of the Index of the Effective Number of Parties will be equal to 2 (Laakso, Taapegera, 1979, p. 4; Kubát, 1998, p. 236). This approach can be compared with the results of Marc van de Wardt's research (2017), which focused on 696 elections in 79 countries between 1945 and 2011.

The Aggregation Index (Mayer, 1980) measures the position and voting power of the strongest party in parliament in relation to other parties within the system.

$$
A=\frac{S}{N}
$$

In this formula, $A$ represents the resulting value of the Aggregation Index, $S$ is the percentage of the seats of the strongest party in parliament, $N$ is determined by the total number of parties in parliament. The higher the index value, the more concentrated the party system. Relative stability of governments should be the result of this. The high value of aggregation means that there is a strong party in the system capable of forming a government - whether a coalition government or a one-party government. This should ensure the stability of the government (Kubát, 1998, p. 237; Lebeda, 2019, p. 578-579). An example of the use of this formula is research by Jin-Young Kwak and Kenneth Janda (2010) aimed to comparative indicators of party systems applicable to studies of measuring the party systems.

\section{CHANGES IN THE SLOVAK PARTY SYSTEM IN 1992-2020}

The dynamics of the development of the Slovak party system can be captured by a direct comparison of the electoral gains of individual political parties. The next part based on the defined comparative indicators then comprehensively complements the overall analysis. The aim is to show how 
Slovak party system has changed over the last almost 30 years through the lens of selected approaches and what trends can be traced.

\subsection{Individual political parties and movements}

Firstly, the focus needs to be devoted to individual political actors. Between 1992 and 2020, the electoral gains of a total of 23 entities can be compared, while some of them won repeatedly. As Table 1 shows, there is no party that would be permanently represented in the Parliament throughout the period 1992-2020 (comp. Chavát, Just, 2018, p. 45). Jakub Charvát and Petr Just (2018, p. 45) speak in this context about "core parties" of the Slovak party system: SNS, SMER-SD, KDH, and SDKÚ-DS.

This points, among other things, to the fact that (repeated) electoral success for a party does not ensure a future successful institutionalization. At the same time, it can be noticed that the party system is able to generate new and successful political parties capable to reach mandates, even repeatedly.

As already mentioned above, there is not entity identified that would be successful in terms of gaining seats after each election. In this respect, SMER is the most successful party in the period under review with six participations in a row, followed by HZDS with five participations in a row. A total of six participations, with breaks, however, were recorded by the following entities - KDH and SNS.

Table 1: Gains of Parliamentary Parties 1992-2020 (in \%)

\begin{tabular}{|c|c|c|c|c|c|c|c|c|c|}
\hline & ๙̃ & హ̆ & $\begin{array}{l}\infty \\
\text { ğ }\end{array}$ & $\underset{\text { ํ. }}{\text { ঠे }}$ & $\begin{array}{l}\text { ঠ̊ } \\
\stackrel{ᄋ}{0}\end{array}$ & $\underset{\text { ㅇ }}{\stackrel{0}{0}}$ & 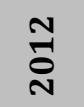 & 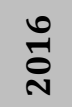 & 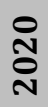 \\
\hline HZDS & 37.26 & 34.96 & 27.00 & 19.50 & 8.79 & - & - & - & - \\
\hline SV & - & 10.41 & - & - & - & - & - & - & - \\
\hline MKM & 7.42 & - & - & - & - & - & - & - & - \\
\hline MK & - & 10.18 & - & - & - & - & - & - & - \\
\hline KDH & 8.89 & 10.08 & - & 8.25 & 8.31 & 8.52 & 8.82 & - & - \\
\hline DEÚS & - & 8.50 & - & - & - & - & - & - & - \\
\hline ZRS & - & 7.34 & - & - & - & - & - & - & - \\
\hline SNS & 7.93 & 5.40 & 9.07 & - & 11.73 & 5.07 & - & 8.64 & - \\
\hline
\end{tabular}




\begin{tabular}{|c|c|c|c|c|c|c|c|c|c|}
\hline SDK & - & - & 26.33 & - & - & - & - & - & - \\
\hline SDL & 14.70 & - & 14.66 & - & - & - & - & - & - \\
\hline SMK & - & - & 9.12 & 11.16 & 11.68 & - & - & - & - \\
\hline SOP & - & - & 8.01 & - & - & - & - & - & - \\
\hline SDKÚ-DS & - & - & - & 15.09 & 18.35 & 15.42 & 6.09 & - & - \\
\hline SMER-SD & - & - & - & 13.46 & 29.14 & 34.79 & 44.41 & 28.28 & 18.29 \\
\hline KSS & - & - & - & 6.32 & - & - & - & - & - \\
\hline ANO & - & - & - & 8.01 & - & - & - & - & - \\
\hline $\begin{array}{c}\text { MOST- } \\
\text { HÍD }\end{array}$ & - & - & - & - & - & 8.12 & 6.89 & 6.50 & - \\
\hline SaS & - & - & - & - & - & 12.14 & 5.88 & 12.10 & 6.22 \\
\hline OL'aNO & - & - & - & - & - & - & 8.55 & 11.02 & 25.02 \\
\hline $\begin{array}{c}\text { SME } \\
\text { RODINA }\end{array}$ & - & - & - & - & - & - & - & 6.62 & 8.24 \\
\hline \begin{tabular}{c} 
\#SIEŤ \\
\hline $\begin{array}{c}\text { LS Naše } \\
\text { Slovensko }\end{array}$
\end{tabular} & - & - & - & - & - & - & - & 5.60 & - \\
\hline \begin{tabular}{c} 
ZA L'UDÍ \\
\hline
\end{tabular} & - & - & - & - & - & - & - & - & 5.77 \\
\hline
\end{tabular}

Source: Volby.statistics.sk, 2020

If the comparison focuses on the dimension of individual parliamentary elections ${ }^{9}$, then Figure 1 makes it clear that the number of parties standing in the elections oscillated around 21 (with the average value of 21.56). The smallest number of entities standing in the elections was 17 , while the highest was 26. The number of successful parties was most often around 6 (the average value is 6.33), when the lowest number of entities was 5 , and the highest 8.

\footnotetext{
${ }^{9}$ In the 1994 elections, Spoločná vol'ba (SV) stood in the elections, coalition parties: Strana demokratickej l'avice, Sociálnodemokratická strana Slovenska, Strana zelených na Slovensku, Hnutie polnohospodárov Slovenskej republiky. In the 1998 elections, the SDK stood in the elections, which was considered a new party. It was first formed as a coalition of five parties (KDH, DÚ, SDSS, DS and SZS), then it transformed into a political party. The number of parties standing in the elections in 2020 does not include Hlas Pravice, which resigned on 20 February 2020 in favor of SaS (see Volby.statistics.sk, 2020).
} 
Figure 1: The Number of Parties Standing in the Elections vs. the Number of Those Elected in the 1992-2020 Parliamentary Elections

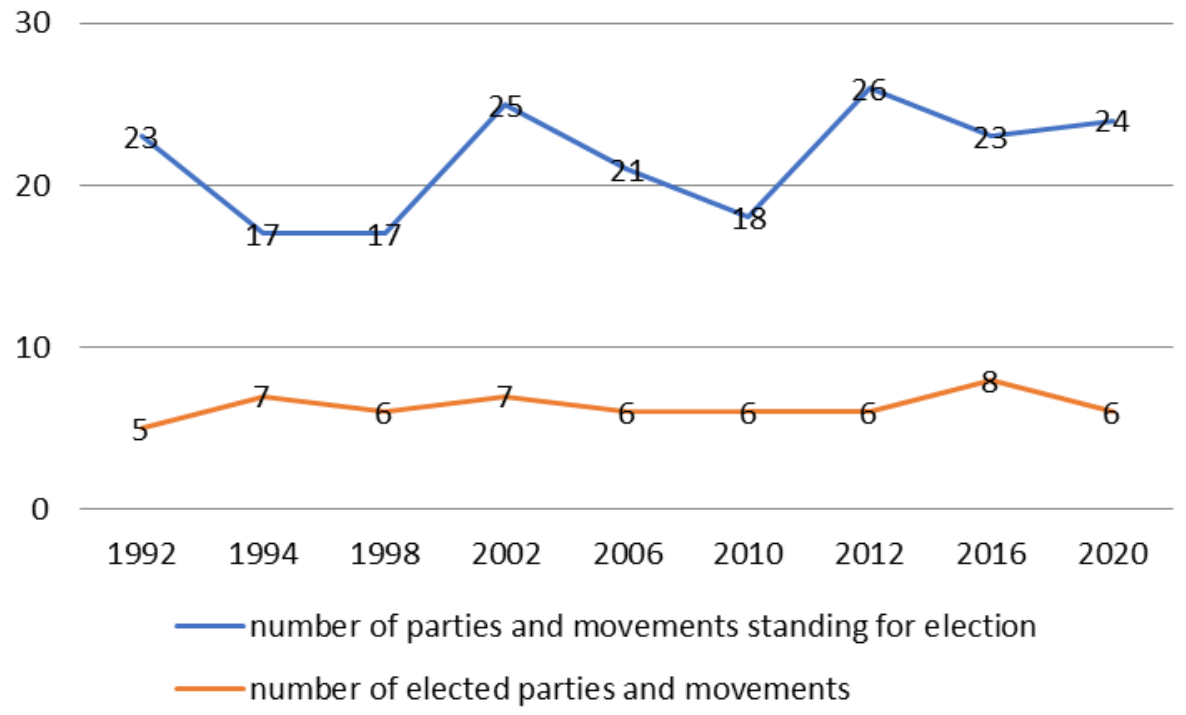

Source: Original elaboration based on Volby.statistics.sk, 2020

The comparison also shows that after the 2010 elections, the number of entities standing in the elections was not under 23, but the number of elected entities reached the value of 8 only in 2016. Otherwise, since 2006 this number has remained at the value of 6 . Although in the last 2020 elections, the number of parties standing in the elections increased by 1 to 24 when compared to the 2016 elections, the number of elected parties decreased by 2 from 8 to 6 .

It turned out that although the number of candidate parties changed almost always over time, the number of elected entities remained more or less the same. No major fluctuations are presented here, nor any a long-term relationship between the number of candidate and successful parties.

\subsection{Index of the Effective Number of Parties}

Development of Index of the Effective Number of Parties optics is crucial to be explained at first. As already outlined in Part 2 Data and Methods, this index can be applied in two variants: at the parliamentary and electoral level. Figure 2 shows that the development has changed significantly over time at both levels. 
Figure 2: Effective Number of Parties in the Elections to the National Council of the Slovak Republic 1992-2020

10

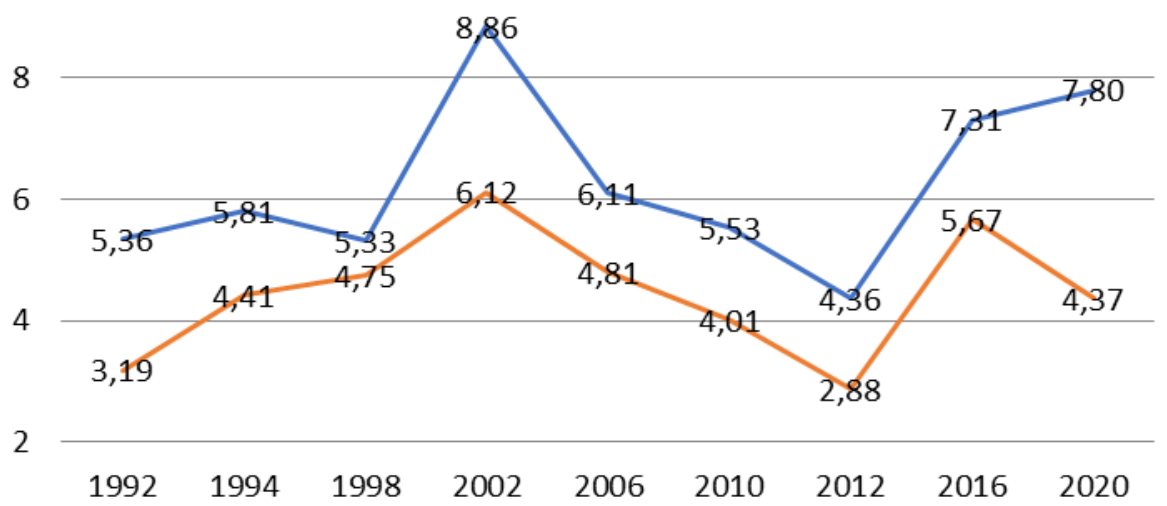

— Effective Number of Electoral Parties

- Effective Number of Parliamentary Parties

Source: Own elaboration according to Volby.statistics.sk, 2020

Looking at the development of the absolute number of parties and the effective number of parties, it is possible to observe that even if the absolute number of parties is without significant fluctuations, the effective number of parties changes more significantly over time. This indicates a change of parties within the Parliament; a mutual electoral size and strength of parliamentary parties are changing. Figure 2 shows that the 1990s can be identified as a period free of any significant fluctuations. This was mainly due to the results of such entities as HZDS, as a long-term strong formation, but also SDL', KDH or SNS.

A fundamental difference is evident in the 2002 elections, when the effective number of electoral and parliamentary parties fluctuated upwards. The reason for this change rested not only in the fall of HZDS, but also in the gains of other parties that achieved representation in the National Council. In addition, in the 2002 elections, SMER-SD and SDKÚ-DS recorded doubledigit results in their first participation.

In 2002, there was a significant increase in electoral instability, which was measurable, for example, also by the volatility index. The Index of the Effective Number of Electoral and Parliamentary Parties shows such increase. The seats were won by a total of seven political groupings (SDKÚ- 
DS, SMER-SD, HZDS, KSS, SMK, KDH and ANO). On the other hand, mutual voting power and a relative size of parties were relatively small.

In the next elections, the absolute number of parliamentary parties dropped to six, and at the same time, the electoral strength of the SMER-SD party gradually began to grow. Figure 1 notes that although the number of parties elected was always six between 2006 and 2012, the proportions of their power changed significantly. The 2006 elections showed an increase in the support for SMER-SD, but SNS also returned. HZDS recorded a certain decline.

In terms of the observable trend, a decrease in support for SDKÚ-DS was apparent after the 2010 elections, but on the contrary, there was an increase in the votes for SMER-SD. Parties MOST-HÍD and SaS entered the National Council for the first time. Following the 2012 elections, which were the early elections, OL'aNO party entered as a new entity, and SDKÚ-DS suffered a decline in support. In the elections, however, SMER-SD, whose electoral power has been growing steadily since 2002, received the maximum support so far. In 2012, the party won a total of 83 seats out of 150, which meant that it could form a one-party government. It accounted for $55 \%$ of the seats in the Parliament. This moment is reflected in the smallest value of the effective number of parliamentary parties in the period under review.

Another sharp increase occurred in the 2016 elections. In addition to the new parties - L'SNS and SME RODINA entering the Parliament, the nationalist SNS also returned to the Parliament. There was a further modification of mutual powers not only in the party system as a whole, but also in the number of parliamentary parties and their electoral power. Although SMER-SD won, it failed to repeat the overwhelming victory from the previous elections. The strength of the opposition gradually increased, with SaS and OLaNO-NOVA parties being the second and third strongest groupings. The fragmentation of the party system was also reflected in the conflicts between the parties.

The 2020 elections confirmed the declining support for SMER-SD party, and, conversely, the rapid increase in the support for OLaNO movement. Neither Siet' nor MOST-HÍD defended their seats, the new ZA L'UDÍ party enjoyed their success. The PS/SPOLU coalition very closely missed its chance to enter the Parliament. ${ }^{10}$ This generally observable development of the chosen index can be empirically proven and confirmed.

${ }^{10}$ See Chapter 4 below. 


\subsection{The Aggregation Index}

A complex research requires to capture the trend with another comparative indicator. If the development of the Slovak party system is captured by the values of the Aggregation Index, then according to Figure 3 it turns out that higher values indicate a relatively lower number of parties in the Parliament with a dominant result of one political party. In 1992, it was HZDS, in 2012 it was SMER-SD party. The results generally correspond to both voter volatility and, in particular, the results obtained when examining the effective number of parties.

Figure 3: Aggregation Index in the Elections to the National Council of the Slovak Republic 1992-2020

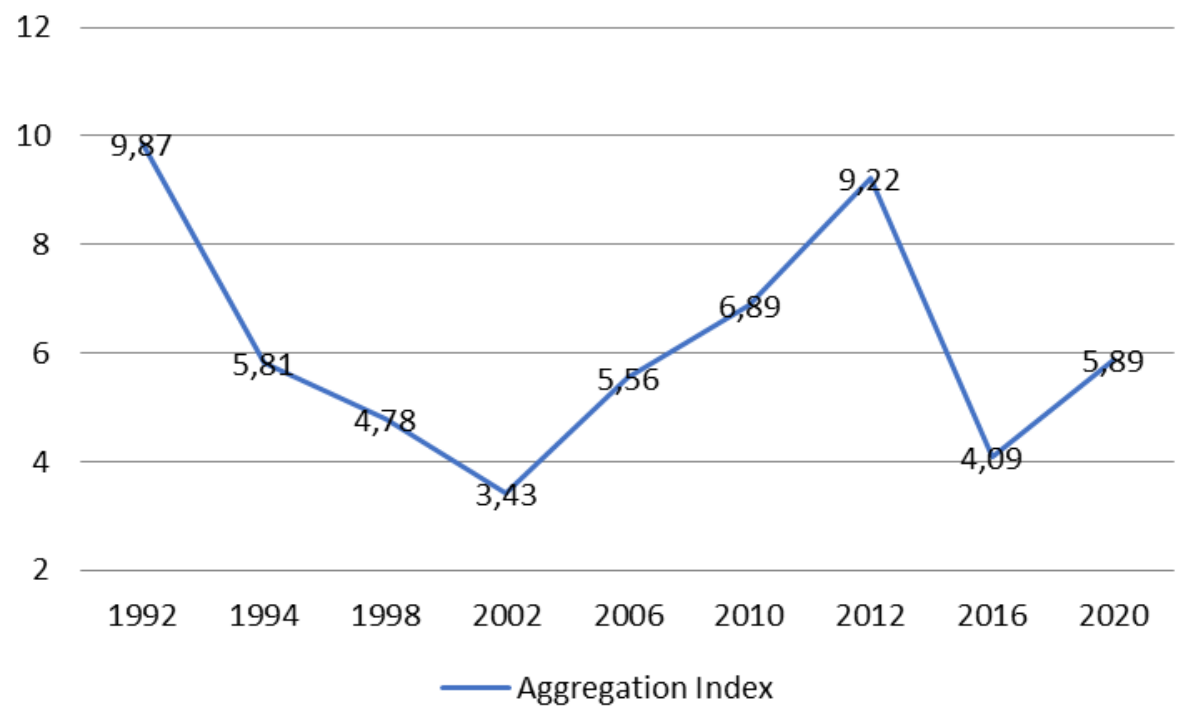

Source: Original elaboration based on Volby.statistics.sk, 2020

In the 1990s, the value of the index gradually declined. The lowest value of the Aggregation Index from 2002 reflects the relatively high fragmentation of the party system, as none of the parties was significantly dominant. Between 2002 and 2006, there was an increase that mimics the growing importance of SMER-SD. The decline was evident in 2016, when other parties succeeded, and SMER-SD weakened. 
On the contrary, the 2020 elections are captured in the context of the relatively important role of OLaNO, and thus the value of the index is growing again. Once more, it is possible to prove the sketched development through the calculation of the given index.

\section{NEW TENDENCES AFTER THE 2020 PARLIAMENTARY ELECTIONS}

The 2020 elections to the National Council of the Slovak Republic were held in connection with completely unprecedented previous events. A specific phenomenon was the rise of the far right and the problematic link between the controversial people towards the state apparatus.

Probably the most serious event, which happened shortly before the elections, one was the murder of journalist Ján Kuciak and his fiancée Martina Kušnírová in February 2018. Slovakia experienced mass protests in the streets. This also led to the resignation of the Prime Minister Robert Fico in March 2018, who, however, remained the chairman of SMER-SD (Filipec, 2019, p. 16).

There were voices claiming that the election campaign was one of the most escalated ones since 1990. This was also due to a number of other criminal cases (see Sekerák, 2019, pp. 234-235), which were gradually released public in the Slovak society. Already in the pre-election period, the decline of the SMER-SD party was noticeable, but it had already been visible for a long time then. ${ }^{11}$

The tandem of Robert Fico as chairman of the SMER-SD party and Peter Pellegrini as Prime Minister and SMER-SD election leader could also be confusing for many potential voters (see Hynčica, 2020). Above all, this was in sharp contrast to the hitherto common practice of a clear leader, who was the chairman of the party. SMER-SD entered the elections as probably the most successful party in era of independent Slovakia. However, the party's position was significantly influenced by the affairs of its leaders.

On the contrary, the OLaNO movement was a favourite party of the elections. It was the party that was able to significantly and constantly point to the problems of the then governing coalition. This due to political communication effectively set up, and the overall concept of political

\footnotetext{
${ }^{11}$ By analogy, it suggests itself to mention the situation of the ČSSD, when before the October elections to the Chamber of Deputies in 2017, the then leader and chairman Bohuslav Sobotka ended in June. In June 2017, the then statutory deputy chairman and Minister of the Interior Milan Chovanec was entrusted with the management of the party, and the then Minister of Foreign affairs and deputy chairman of the party Lubomír Zaorálek became the election leader.
} 
marketing of this political project. This is to some extent related to the very essence of the OLaNO movement. The movement is sometimes referred to as a populist party, or possibly the business-firm party. OLaNO, just as ANO (a party that no longer exists today), SaS and SME RODINA are analyzed by Juraj Marušiak in terms of entrepreneur parties (Marušiak, 2017). OL'aNO had only four members for a long time. In the autumn of 2019, it reached around 6\% in the polls; however, before the elections, its support was already around $19 \%$. This rise was gradual and was reflected by nearly all the preelection polls. In addition to effective self-defining against the coalition, for example, a program called "Honestly, Courageously, For the People" was another important protest signal. However, some commentators (Havlická, 2020; Zelenka, 2020 or Kubátová, 2021) have highlighted the party's excessive populist elements.

The far-right entity - L'SNS party, supported before the elections by more than $10 \%$, did not escape attention either. This party garnered voter support mainly among young segments of the population. For many voters, the support of this party was the embodiment of dissatisfaction, resistance and protest against the establishment in general (Linek, Gyárfášová, 2020).

Table 2: Elections to the National Council of the Slovak Republic 2020

\begin{tabular}{|c|c|c|c|}
\hline & $\begin{array}{c}\text { Number of votes } \\
\text { (in \%) }\end{array}$ & $\begin{array}{c}\text { Number of votes } \\
\text { (abs.) }\end{array}$ & Number of seats \\
\hline OL'aNO & 25.02 & 721166 & 53 \\
\hline SMER-SD & 18.29 & 527172 & 38 \\
\hline SME RODINA & 8.24 & 237531 & 17 \\
\hline L'SNS & 7.97 & 229660 & 17 \\
\hline PS/SPOLU & 6.96 & 200780 & 0 \\
\hline SaS & 6.22 & 179246 & 13 \\
\hline ZA L'UDí & 5.77 & 166325 & 12 \\
\hline
\end{tabular}

Source: Volby.statistics.sk, 2020

And the election results? The success of the OLaNO movement led by former businessman Igor Matovič was quite a crucial event. However, Igor Matovič entered politics in early 2010, as a candidate of the liberal entity called SaS. In the media during the 2020 elections and even after the elections, there appeared voices that Igor Matovič is similar in his political 
style to the Prime Minister of the Czech Republic Andrej Babiš (comp., e.g., Šárovec, 2018).

This center-right liberal movement, sometimes referred to as populist, achieved the highest election result in its history. OL'aNO characterizes itself as "an honest anti-corruption movement aimed at defeating corrupt politicians and their political parties." (Obycajniludia.sk, 2020; comp. Sekerák, 2020) The movement was able skilfully to take advantage of the growing negative sentiments towards the SMER-SD party and the personality of the long-time Prime Minister Robert Fico.

The movement was able to reach out to the voters demanding a change. Anti-corruption references, which were present throughout the entire electoral campaign, were very strong. In connection with the elections, the Slovak media reported on the victory of anti-corruption populism and the defeat of the liberals (this issue was elaborated in past by Mihálik, 2017; Gyárfášová, 2018; Hynčica, 2019; Engler, 2020 or Mesežnikov, 2020).

The election results pointed to the (temporary?) end of the dominant era of the SMER-SD party (see, e.g., Karabová, Filipec, 2018 and Just, 2019), which recorded the second worst result in its history and after 12 years in power ${ }^{12}$ it headed into opposition. At the same time, a voter turnout at $65.8 \%$ was the highest in 14 years (Volby.statistics.sk, 2020). This is very different, for example, from the elections to the European Parliament, where Slovakia has traditionally displayed an extremely low turnout (Gyárfášová, Henderson, 2018; comp. with europeanization of Slovak political parties in Leška, 2015 or Karabová, Filipec, 2018).

In addition, former Prime Minister Peter Pellegrini announced his departure from SMER-SD party in June 2020 and indicated the establishment of a new political formation. ${ }^{13}$ Publicly, this situation was described as the peak of a split in the party. Some tension was expected already before the 2020 elections. In addition, Pellegrini called on the party's founder, Robert Fico, to resign already during the post-election period.

\footnotetext{
${ }^{12}$ In 2006-2010 it was the first government of Robert Fico, in 2012-2016 the second government of Robert Fico, in 2016-2018 the third government of Robert Fico and in the period 2018-2020 the government of Peter Pellegrini. The only exception in this period were the years 2010-2012, when Iveta Radičová was Prime Minister and SDKÚ-DS, SaS, KDH and MOST-HÍD participated in the government.

${ }^{13}$ In the end, this step really did happen; he founded the HLAS - sociálna demokracia party. Here, a parallel can be found again with another new Czech entity, namely the HLAS political movement of the former European Commissioner and MEP Pavel Telička, founded in 2019 (Šárovec, 2020, p. 78). Comp. with parties' expert capacities (Jágr, 2020).
} 
SME RODINA placed third with some gap left behind the first two political entities. This hard-to-grasp movement focused on populist and socialconservative ideas (see Školkay, Žúborová, 2019) was able to improve its 2016 election result and enhanced its number of seats by 3 .

Although L'SNS recorded a relatively high support before the elections, in the end it failed to turn it into the election result comparable to the election poll. The rise of the far right thus did not happen and the Party recorded a turnout comparable to the 2016 elections, when its turnout was one of the relatively big surprises (see, e.g., Filipec, 2017; Harris, 2019 or Vasil'ková, Androvičová, 2019). Even so, the Party also improved its position and won a total of 17 seats, i.e. also 3 more.

In the end, the PS/SPOLU coalition, which needed seven percent of the votes, narrowly missed its chance to enter the parliament. The liberal coalition needed to earn a total of seven percent of votes, but it only reached 6.96 percent, which means it lacked 927 votes (Volby.statistics.sk, 2020). Some commentaries spoke of the loss of the liberal coalition or of the biggest loser of the elections (e.g., Kubátová, 2020).

It showed that standing in the elections in a coalition may not be advantageous in some cases. The result was surprising also because the coalition won the elections in Slovakia to the European Parliament in 2019 and the current president Zuzana Čaputová also arose from Progresívne Slovensko (PS), which was a member of the coalition with SPOLU.

The liberal or libertarian grouping SaS and the predominantly liberal party ZA L'UDÍ of former President Andrej Kiska recorded a similar turnout. These two entities suffered an outflow of their voters turned towards the winner of the elections - OL'aNO (Mesežnikov, 2020). For SaS, it was the worst electoral result since 2010; on the contrary, ZA L'UDÍ party stood in general elections for the first time as a new party.

Due to post-electoral negotiations, a coalition government was formed, consisting of OL'aNO, SME RODINA, SaS and ZA L'UDÍ, chaired by Igor Matovič as Prime Minister, and with Richard Sulík, Veronika Remišová and Štefan Holý as vice-chairs (Vlada.sk, 2020). SMER-SD and L'SNS stay in opposition. The government coalition seeks to rid Slovakia of the "legacy" left by the SMER-SD party after its rule. The onset of government and the first months of its operation took place in very non-standard conditions of the first wave of the COVID-19 pandemic caused by the coronavirus SARS-CoV-2. 


\section{CONCLUSION}

The presented study has analysed dynamics of the development of the party system in Slovakia. Elections to the National Council of the Slovak Republic were held at a time when the murder of a journalist and his fiancée was an important topic in the society. Popularity of the far right grew in Slovakia, but the connection of controversial persons towards the state apparatus was also revealed.

The question to be answered was therefore not only how the elections would turn out, but what trend the development of the elections would show. The article focused on the dimension of individual electoral parties in the context of each elections from 1992 to 2020. The Index of the Effective Number of Parties and the Aggregation Index served as tool for further analysis.

From the aspect of individual political entities, it turned out that the number of parties standing in the elections was rather fluctuating and did not fall below 23 in the last three elections (2012, 2016 and 2020). On the other hand, the number of the parties that entered the Parliament did not change significantly then. After the 2016 elections, when 8 entities were represented in the Parliament, their number returned to the highest value of 6 in the 2020 elections. The Index of the Effective Number of Parties and the Aggregation Index then pointed to the clear swings in the development of the party system. Seen through the prism of the monitored comparative indicators, so far, the 2020 elections have proved to be of a significant change.

The 2020 elections to the National Council of the Slovak Republicrepresent another argument for the supporters of a rather lower degree of the party system stability. The elections have significantly redrawn the political map of Slovakia and spread a clear message that most of the Slovak society had been calling for a change. OL'aNO's victory was also expected in connection with the pre-election polls, but not to such an overwhelming extent. After many years, the government was not formed by SMER-SD party. Following the election results and the consequent post-election developments, a more fundamental ideological and a partial personnel change is likely to await this party.

This is the first time since the fall of communism in 1989, when a large Hungarian minority, making up $8.5 \%$ of Slovakia's population, is not represented in Parliament. Increase in the support for controversial far-right forces represented by L'SNS party was not confirmed against the election polls. For the second time in a row, none traditional moderate conservative pro-European party - KDH did earn a single seat in the Parliament. 
In conclusion, the results of the 2020 elections point to a renewed significant change in the dynamics of party-political competition, at least in terms of the change of the ruling coalition and the distribution of forces of individual actors. Although the coalition government led by the Prime Minister Igor Matovič with a reputation of an unpredictable politician begun its work, it is too early for a more comprehensive assessment.

It is necessary to point out the development t to April 2021, especially the role of Igor Matovič within the coronavirus crisis and his resignation from the Prime Minister's seat. There were made couple of changes within the other government positions. During the government crisis, which began to escalate at the time of the secret purchase of the Russian vaccine Sputnik V against coronavirus, a total of six ministers left the cabinet. Igor Matovič has been appointed the Minister of Finance. The new Prime Minister is Eduard Heger (OLaNO) from April 2021 (iROZHLAS.cz, 2021).

A breakthrough in the development trend is a great challenge for further research. It will either confirm a more general change in the distribution of forces in the Slovak party system, or it will classify the analyzed 2020 elections only as an extraordinary fluctuation.

\section{REFERENCES}

BAER, J. (2001). Boxing and Politics in Slovakia: 'Meciarism' Roots, Theory, Practice. In: Democratization.Vol. 8, No. 2, pp. 97-116.2001. DOI: https:// doi.org/10.1080/714000200.

BAKKE, E., SITTER, N. (2015). Where do parties go when they die? The fate of failed parties in the Czech Republic, Slovakia, and Hungary 1992-2013. In: East European Politics. Vol. 31, No. 1, 2015. pp. 1-22. DOI: https://doi. org/10.1080/21599165.2014.959661.

BARDOVIČ, J. (2016). Politické strany - pragmatický aktér v procese tvorby politiky? In: Slovenská revue pre verejnú politiku a verejnú správu/Slovak Journal of Public Policy and Public Administration. Vol. 3, No. 2, 2016. pp. 99-110.

BRUNCLÍK, M. (2014). Švédský stranický systém po parlamentních volbách v roce 2014. In: Politologická revue/Czech Political Science Review. Vol. 20, No. 2, 2014. pp. 141-160.

CABADA, L., HLOUŠEK, V., JUREK, P. (2013). Ztraceny $v$ tranzici? Minulost a prítomnost politického stranictví ve střední a východní Evropě. Brno: Fakulta sociálních studií Masarykovy univerzity/Mezinárodní politologický ústav, 2013. 213 pp. 
DEEGAN-KRAUSE, K. (2006). Elected affinities: democracy and party competition in Slovakia and the Czech Republic. Stanford: Stanford University Press, 2006. 352 pp.

DEEGAN-KRAUSE, K., HAUGHTON, T. (2015). Hurricane Season. Systems of Instability in Central and East European Party Politics. In: East European Politics \& Societies. Vol. 29, No. 1, 2015. pp. 61-80. DOI: https://doi. org/10.1177/0888325414566072.

ENGLER, S. (2020). Centrist anti-establishment parties and their protest voters: more than a superficial romance? In: European Political Science Review. Vol. 12, No. 3, 2020. pp. 307-325. DOI: https://doi.org/10.1017/ S1755773920000132.

FILIPEC, O. (2017). People's Party - Our Slovakia: An Anti-System Party? In: Current Trends and Public Administration (conference proceeding). Uherské Hradiště: Faculty of Administration and Economic Studies in Uherské Hradiště, Jagiellonian College in Toruń, 2017. pp. 21-30.

FILIPEC, O. (2019). Challenging Trends within Slovak Party System in the Context of 2016 Elections to the National Council of the Slovak Republic. In: Politics in Central Europe. Vol. 15, No. 1, 2019. pp. 7-34. DOI: https:// doi.org/10.2478/pce-2019-0001.

FISH, S. M. (1999). The End of Meciarism. In: East European Constitutional Review. Vol. 8, No. 1 \& 2, 1999. pp. 47-55.

FRIČ, P., GYÁRFÁŠOVÁ, O. (2019). The Rise of the Politics of Emotions: Antielitism and Anti-Corruptism as Traits of Czech and Slovak Populist Parties. In: Politické vedy/Political Sciences. Vol. 22, No. 4, 2019. pp. 221246. DOI: https://doi.org/10.24040/politickevedy.2019.22.4.221-246.

GYARFÁŠOVÁ O., MESEŽNIKOV, G. (2004). Vláda strán na Slovensku: skúsenosti a perspektivy. Bratislava: IVO, 2004, 156 pp.

GYÁRFÁŠOVÁ, O., BAHNA, M., SLOSIARIK, M. (2017). Sila nestálosti: volatilita voličov na Slovensku vo vol'bách 2016. In:Středoevropsképolitické studie/ Central European Political Studies Review. Vol. 19, No. 1, 2017. pp. 1-24. DOI: https://doi.org/10.5817/CEPSR.2017.1.1.

GYÁRFÁŠOVÁ, O. (2018). The fourth Generation: From anti-establishment to anti-system parties in Slovakia. In: New Perspectives. Vol. 26, No. 1, 2018. pp. 109-133. DOI: https://doi.org/10.1177/2336825X1802600111.

GYÁRFÁŠOVÁ, O., HENDERSON, K. (2018). Slovakia and the turnout conundrum. In: East European Politics. Vol. 34, No. 1, 2018. pp. 77-96. DOI: https://doi.org/10.1080/21599165.2017.1419189. 
GYÁRFÁŠOVÁ, O. (2020). Slovenské vol’by 2020: potvrdenie „stabilnej nestability" [online]. Heinrich Böll Stiftung [Accessed 2020-11-15]. Available at: <https://cz.boell.org/cs/Slovak_elections_2020>.

HARRIS, E. (2019). Nation before democracy? Placing the rise of the Slovak extreme right into context. In: East European Politics. Vol. 35, No. 4, 2019. pp. 538-557. DOI: https://doi.org/10.1080/21599165.2019.1667770.

HAVLICKÁ, K. (2020). Pohádal by se i sám se sebou. Slovensko může ř́́dit neř́zená střela Matovič. [online]. iDNES.cz. 14. 2. 2020 [Accessed 2021-7-12]. Available at: <https://www.idnes.cz/zpravy/zahranicni/ igor-matovic-olano-slovensko-volby-parlament.A200212_123922_ zahranicni_kha>.

HYNČICA, P. (2019). Krize a kontinuita „starých“ a nástup nových politických stran na Slovensku. In: Central European Journal of Politics. Vol. 5, No. 1, 2019. pp. 55-70.

HYNČICA, P. (2020). Politolog: Slovenské volby se konají v rozjitřené atmosféře, jde o nejvyhrocenější kampaň od roku 1990. In: Prima.iprima. $c z$ [online]. [Accessed 2020-11-15]. Available at: <https://prima.iprima. cz/zpravodajstvi/politolog-slovenske-volby-se-konaji-v-rozjitreneatmosfere-jde-o-nejvyhrocenejsi>.

HYNČICA, P., ŠÁROVEC, D. (2018). Slovenské politické strany optikou konceptu novosti. In: Acta Fakulty filozofické Západočeské univerzity v Plzni/The Faculty of Philosophy and Arts Review. Vol. 10, No. 2-3, 2018. pp. 7-34. DOI: https://doi.org/10.24132/actaff.2018.10.2-3.1.

CHARVÁT, J., JUST, P. (2018). Politické zemětřesení 2016? Dynamika stranického systému na Slovensku od roku 2002. In: Politické vedy/ Political Sciences. Vol. 21, No. 1, 2018. pp. 24-57. DOI: https://doi. org/10.24040/politickevedy.2018.21.1.24-57.

IROZHLAS.CZ. (2021). Slovensko má nového premiéra. Matoviče vystřídal dosavadní ministr financí Heger. In: Irozhlas.cz. [online]. [Accessed 202104-13]. Available at: <https://www.irozhlas.cz/zpravy-svet/slovenskopremier-eduard-heger-igor-matovic_2104011015_ako>.

JÁGR, D. (2020). Parliamentary research services as expert resource of lawmakers. The Czech way. In: The Journal of Legislative Studies. Latest articles, pp. 1-29. DOI: https://doi.org/10.1080/13572334.2020.18311 27.

JUST, P. (2018). Pod Tatrou sa blýska: strany, vlády a koalice na Slovensku v letech 2006 až 2016. Praha: Metropolitan University Prague Press and Libri, 2018. 164 pp. 
JUST, P. (2019). Slovak cabinet after 2016: from single party majority to motley crew. In: Journal of Comparative Politics. Vol. 12, No. 1, 2019. pp. 71-85.

KARABOVÁ, D., FILIPEC, O. (2018). The Europeanization of Slovak Political Parties: the Case of Směr - Social Democracy, the Slovak National Party and Most-Híd. In: Contemporary European Studies. Vol. 13, No. 2, 2018. pp. 5-29.

KEREKEŠ, D., PINK, M., ŠEDO, J. (2019). Slovenské stranické zemětřesení 2016. Pomohla by malá volební reforma? In: Sociológia/Slovak Sociological Review. Vol. 51, No. 1, 2019. pp. 64-83.

KIRSCHBAUM, S. (2002). Book Review on Slovakia after Communism and Mečiarism. Ed. Kieran Williams. In: Slavic Review. Vol. 61, No. 1, 2002. pp. 138-139. DOI: https://doi.org/10.2307/2696994.

KOPEČEK, L. (2006). Slovensko. In: STRMISKA, M., HLOUŠEK, V., KOPEČEK, V., CHYTILEK, R. Politické strany moderní Evropy. Analýza stranickopolitických systémů. Praha: Portál, 2006. pp. 453-479.

KOSOWSKA-GĄSTOŁ, B., SOBOLEWSKA-MYŚLIK, K. (2019). New parties in the Polish party system 2011-2018: The Palikot Movement, Kukiz'15 and the Modern Party of Ryszard Petru as genuinely new parties? In: Central European Journal of Politics. Vol. 5, No. 1, 2019. pp. 6-29. DOI: https:// doi.org/10.2478/pce-2019-0004.

KUBÁT, M. (1998). Volby, fragmentace a polarizace stranického systému a politická nestabilita v České republice. In: Politologický časopis/Czech Journal of Political Science. Vol. 5, No. 3, 1998. pp. 231-243.

KUBÁTOVÁ, E. (2020). Pád Smeru, úspěch Matoviče a Madaři bez zastoupení. Pět hlavních událostí voleb na Slovensku. In: iROZHLAS.cz [online]. [Accessed 2020-11-15]. Available at: <https://www.irozhlas. cz/zpravy-svet/slovensko-volby-2020-igor-matovic-robert-fico-olanosmer_2003011108_eku>.

KWAK, J. Y., JANDA, K. (2010). Measuring Party System: Revisiting Competitiveness and Volatility in Parliamentary Party Systems. In: The Korean Journal of Area Studies. Vol. 28, No. 2, 2010. pp. 21-49.

LAAKSO, M., TAAGEPERA, R. (1979). "Effective" Number of Parties: A Measure with Application to West Europe. In: Comparative Political Studies. Vol. 12, No. 1, 1979. pp. 3-27. DOI: https://doi. org/10.1177/001041407901200101.

LEBEDA, T. (2019). Nástroje $\mathrm{k}$ měření volebních výsledků a vlastností stranických systémů. In: NOVÁK, M. et. al. Úvod do studia politiky. Praha: Sociologické nakladatelství SLON, 2019, pp. 569-580. 
LEŠKA, D. (2013). Hlavné etapy formovania systému politických strán na Slovensku po roku 1989. In: Sociológia/Slovak Sociological Review. Vol. 45, No. 1, 2013. pp. 71-88.

LEŠKA, D. (2015). The Europeanisation of Slovak Political Parties. In: Slovak Journal of Political Sciences. Vol. 15, No. 1, 2015. pp. 31-58. DOI: https:// doi.org/10.1515/sjps-2015-0003.

LINEK, L., GYÁRFÁŠOVÁ, O. (2020). The Role of Incumbency, Ethnicity, and New Parties in Electoral Volatility in Slovakia. In: Politologický časopis/ Czech Journal of Political Science. Vol. 27, No. 3, 2020. pp. 303-322. DOI: https://doi.org/10.5817/PC2020-3-303.

MARUŠIAK, J. (2017). Political Entrepreneurs as a Challenge for the Party System in Slovakia. In: Politologický časopis/Czech Journal of Political Science. Vol. 24, No. 2, 2017. pp. 179-200. DOI: https://doi.org/10.5817/ PC2017-2-179.

MAYER, L. C. (1980). A Note on the Aggregation of Party Systems. In: MERKL, P. ed. Western European Party Systems. New York: Free Press, 1980. pp. 515-520.

MESEŽNIKOV, G. (2013). Rise and Fall of New Political Parties in Slovakia. In: MESEŽNIKOV, G., GYÁRFÁŠOVÁ, O., BÚTOROVÁ, Z. eds. Alternative Politics? The Rise of New Political Parties in Central Europe. Bratislava: Inštitút pre verejné otázky, 2013. pp. 53-82.

MESEŽNIKOV, G. (2020). A political map of Slovakia two years after the tragedy of the murder of Ján and Martina. Heinrich Böll Stiftung [online]. [Accessed 2020-11-15]. Available at: <https://www.boell. de/en/2020/03/11/political-map-slovakia-two-years-after-tragedymurder-jan-and-martina>.

MIHÁLIK, J. (2017). The Electoral Aftermath: New Wave Populism and Radicalism in Slovakia. In: Current Trends and Public Administration (conference proceeding). Uherské Hradiště: Faculty of Administration and Economic Studies in Uherské Hradiště, Jagiellonian College in Toruń, 2017. pp. 9-20.

NAXERA, V., KRČÁL, P. (2017). Perceptions of Slovak Politicians and their Discursive Reification at the Celebrations of the Slovak National Uprising in 2016. In: Studia Politica. Romanian Political Science Review. Vol. 17, No. 2, 2017. pp. 279-294.

NOVOTNÝ, L., ŠÁROVEC, D. (2018). Německý stranický systém a volby do Bundestagu 2017. In: Acta Politologica. Vol. 10, No. 3, 2018. pp. 47-63. DOI: https://doi.org/10.14712/1803-8220/10_2018. 
SEKERÁK, M. (2019). Towards conservatism? Party politics in Slovakia at the end of the 2010s. In: European View. Vol. 18, No. 2, 2019. pp. 233241. DOI: https://doi.org/10.1177/1781685819883965.

SEKERÁK, M. (2020). Neliberálny populizmus na Slovensku: prípad tzv. rodovej ideológie. In: Acta Politologica. Vol. 12, No. 1, 2020. pp. 65-86. DOI: https://doi.org/10.14712/1803-8220/21_2019.

SMOLECOVÁ, A. (2019). Dynamika vývoja slovenského straníckeho systému. Bachelor thesis. Department of Political Science, Institute of Political Studies, Faculty of Social Sciences, Charles University, 2019.

STÍSKALA, J. (2014). Party System of Slovak Republic and its Stability after 2010 and 2012 Elections in Comparative Perspective. In: Slovak Journal of Political Sciences. Vol. 12, No. 3, 2014. pp. 224-251. DOI: https://doi. org/10.2478/sjps-2013-0007.

SZCZERBIAK, A., HANLEY, S. eds. (2006). Centre-right parties in postcommunist East-Central Europe. London, New York: Routledge, 2006. 155 pp.

ŠÁROVEC, D. (2018). Nástup nových politických stran v ČR od roku 2013: hnutí ANO 2011 a Úsvit prrímé demokracie pohledem konceptu novosti. In: Sociológia/Slovak Sociological Review. Vol. 50, No. 1, 2018. pp. 78-113. ŠÁROVEC, D. (2019). Is the "new" always "new"? Theoretical framework problems of new political parties' research: The Czech Republic experience. In: Politics in Central Europe. Vol. 15, No. 1, 2019. pp. 55-80. DOI: https://doi.org/10.2478/pce-2019-0003.

ŠÁROVEC, D. (2020). Konceptuální a metodologické aspekty výzkumu nových politických stran. In: Politologická revue/Czech Political Science Review. Vol. 26, No. 1, 2020. pp. 67-86.

ŠEDO, J. (2008). Volební systémy postkomunistických zemí. Brno: Centrum pro studium demokracie a kultury, 2008, 420 pp.

ŠKOLKAY, A., ŽÚBOROVÁ, V. (2019). Populist Political Movement Sme rodina

- Boris Kollár (We Are a Family - Boris Kollár). In: Środkowoeuropejskie Studia Polityczne. No. 4, 2019. pp. 5-26. DOI: https://doi.org/10.14746/ ssp.2019.4.1.

ŠTEFANČÍK, R., NEMCOVÁ, A. (2015). The System of Political Party Funding as a Sign of Weakly Institutionalized Party System in Slovakia. In: Romanian Journal of Political Science. Vol. 15, No. 2, 2015. pp. 35-62.

VASIL'KOVÁ, A., ANDROVIČOVÁ, J. (2019). Príčiny nárastu podpory pravicového radikalizmu a extrémizmu na Slovensku: príklad politickej strany Kotleba-L'SNS. In: Central European Journal of Politics. Vol. 5, No. 1, 2019. pp. 71-99. 
VLADA.SK (2020). Vlada.sk [online]. [Accessed 2020-11-15]. Available at: $<$ https://www.vlada.gov.sk//clenovia-vlady/>.

VODA, P., PINK, M. (2015). Explanation of spatial differentiation of electoral results in the Czech Republic and Slovak Republic. In: Communist and Post-Communist Studies, Vol. 48, No. 4, pp. 301-316. DOI: https://doi. org/10.1016/j.postcomstud.2015.09.002.

VOLBY.STATISTICS.SK (2020). Štatistický úrad Slovenskej republiky [online]. [Accessed 2020-11-15]. Available at: <https://volby.statistics.sk/index. html>.

VAN DE WARDT, M. (2017). Explaining the effective number of parties: Beyond the standard model. In: Electoral Studies. Vol. 45, 2017. pp. 4454. DOI: https://doi.org/10.1016/j.electstud.2016.11.005.

WILLIAMS, K. ed. (2000). Slovakia after Communism and Mečiarism. London: School of Slavonic and East European Studies, University College, 2000. $131 \mathrm{pp}$.

ZELENKA, F. (2020). Kdo je Igor Matovič a co slovenské politice prozatím přinesl? [online]. In: E15.cz. 2. 3. 2020 [Accessed 2021-7-12]. Available at: <https://www.e15.cz/the-student-times/kdo-je-igor-matovic-a-coslovenske-politice-prozatim-prinesl-1367288>.

ŽÚBOROVÁ, V. (2015). Newcomers in Politics? The Success of New Political Parties in the Slovak and Czech Republic after 2010? In: Baltic Journal of Law \& Politics. Vol. 8, No. 2, 2015. pp. 91-111. DOI: https://doi. org/10.1515/bjlp-2015-0020. 